\title{
PENGARUH DEBT TO EQUITY RATIO, RASIO PASAR DAN TOTAL ASSETS TURN OVER TERHADAP RETURN SAHAM PADA PERUSAHAAN PROPERTY YANG TERDAFTAR DI ISSI
}

\author{
${ }^{1}$ Noni Ayunda Sari, ${ }^{2}$ Sri Rahayu, ${ }^{3}$ Zufrizal, ${ }^{4}$ Lusi Elviani Rangkuti \\ 1.2.3.4 Universitas Islam Sumatera Utara; \\ ${ }^{1}$ sarinoniayunda@gmail.com, ${ }^{2}$ sri.rahayu@fe.uisu.ac.id, ${ }^{3}$ Zufrizal@uisu.ac.id, \\ ${ }^{4}$ lusi.elvianirangkuti@gmail.com
}

\begin{abstract}
This study aims to see how much Debt To Equity Ratio (DER), Market Ratio (Price Book Value) and Total Asset Turn Over (TATO) Influence On Property Companies Listed in ISSI. The number of samples in this study as many as 10 samples of the company and research conducted from 2016-2018. The data analysis methods used to test hypotheses are descriptive analysis test, classic Assumption Test, Multiple linear analysis test, and Hypothesis Test which is processed in a statistical manner and using Statistic for product and service solution (SPSS) program version 25.00 year 2020. The results showed that variable Debt To equity Ratio (DER), Market Ratio (Price book value) and Total Asset Turn Over (TATO) simultaneously have a significant influence on Stock Return. While partially the effect varies, Debt To Equity Ratio and Total Asset Turn Over have no significant effect on Stock Return. While the market ratio (Price Book value) has a significant influence and has a negative direction towards Stock Return.
\end{abstract}

Keywords : Debt To Equity Ratio, Rasio Pasar (Price Book Value), Total Asset Turn Over, Return Saham.

ABSTRAK : Penelitian ini bertujuan untuk melihat seberapa besar Pengaruh Debt To Equity Ratio (DER), Rasio Pasar (Price Book Value) dan Total Asset Turn Over (TATO) Pada Perusahaan Property Yang Terdaftar di ISSI. Jumlah sampel pada penelitiaan ini sebanyak 10 sampel perusahaan dan penelitian dilakukan dari Tahun 2016-2018. Metode analisis data yang digunakan untuk menguji hipotesis adalah Uji analisi deskriptif, Uji Asumsi klasik, Uji analisi linear berganda, dan Uji Hipotesisyang diolah secara seacara statistic dan menggunakan program Statistic for product and service solution (SPSS) versi 25,00 Tahun 2020. Hasil penelitian menunjukan Bahwa variabel Debt To equity Ratio (DER), Rasio Pasar (Price book value) dan Total Asset Turn Over (TATO) secara simultan memberikan pengaruh signifikan terhadap Return Saham. Sedangkan secara parsial pengaruhnya berbeda-beda, Debt To Equity Ratio dan Total Asset Turn Over tidak Berpengaruh signifikan terhadap Return Saham. Sedangkan rasio pasar (Price Book value) brpengaruh signifikan dan memiliki arah yang negatif terhadap Return Saham.

Kata Kunci : Debt To Equity Ratio, Rasio Pasar (Price Book Value), Total Asset Turn Over, Return Saham.

\section{Pendahuluan}

\subsection{Latar Belakang Masalah}

Industri properti merupakan divisi vital terdepan dalam suatu bangsa, karena dapat dimanfaatkan sebagai penunjuk untuk menganalisis kesejahteraan finansial suatu negara. Industri properti juga merupakan salah satu divisi yang memberikan klarifikasi tentang semakin banyaknya perusahaan yang terikat dalam properti dan warisan asli, yang menunjukkan bahwa perekonomian negara sedang berkembang. Usaha di segmen properti bisa menjadi usaha jangka panjang dan akan berkembang sejalan dengan perkembangan keuangan yang diterima sebagai usaha yang menjanjikan. Dalam perluasan berbagai pilihan 
barang spekulasi seperti saham, obligasi, toko bersama dan lain-lain, pameran modal memiliki banyak pilihan divisi industri, salah satunya adalah properti dan industri warisan asli.

Return saham adalah hasil yang didapat dari spekulasi. Return sahamjuga dapat berupa pengembalian yang telah terjadi atau pengembalian yang diantisipasi yang belum terjadi tetapi masih diantisipasi untuk terjadi di masa yang akan datang (Jogianto, 2010: 205).Analisis nilai saham penting dilakukan oleh para investor, terutama yang berkaitan dengan dividen dan laba yang diharapkan dari perusahaan di masa yang akan datang. Besarnya dividen dan laba yang diharapkan dari suatu perusahaan akan tergantung pada prospek yang dimiliki perusahaan dalam menghasilkan laba. Perubahan harga saham dapat terjadi secara tidak terduga dan tidak dapat diperkirakan sebelumnya. Kemampuan perusahaan dalam membayar hutang pada saat jatuh tempo menjadi salah satu daya tarik investor atas saham perusahaan tersebut meningkat sehingga permintaan atas saham perusahaan tersebut meningkat. Debt to equity ratio menunjukkan perbandingan utang dan modal. Selain itu rasio ini dinilai penting karena dapat memberi pengaruh positif dan negatif terhadap rentabilitas modal sendiri dari perusahaan tersebut. Semakin tinggi rasio ini maka semakin rendah kemampuan modal sendiri dalam menjamin hutang jangka panjang.

Rasio pasar dapat diukur dengan Price to Book Value (PBV), Price Earning Ratio (PER),seperti Penelitian oleh Teguh prasetyo (2000) yang menyimpulkan bahwa PBV (Price book Value). Berpengaruh signifikan terhadap return saham. TATO (Total Asset Turn Over) adalah rasio yang menunjukan hubungan antara penjualan netto dengan aktiva tetap. Rasio ini menujukan berapa kali dana yang ditanamkan dalam aktiva tetap berputar dalam satu periode (Munawir ,2007).

Bank Indonesia atau BI menjelaskan bahwa pihak nyasudah mengetahui akan pembelian secara spekulatif karenanya Bank Indonesia membuat kebijakan pengetatan moneter, karena permintaaan domestik untuk properti tetap besar dan kebanyakan pembelian dilakukan oleh pengguna akhir, sementara harga properti meskipun telah meningkat cepat masih tergolong rendah dibandingkan kota-kota lain di Asia.
Menjadi semakin umum bahwa para investor Indonesia membeli beberapa unit dan menjualnya dengan keuntungan yang tinggi, sebelum proses konstruksi bangunan di mulai. Biasanya sebuah unit berpindah kepemilikan beberapa kali sebelum proses konstruksi selesai, dalam setiap kali pembelian harga menjadi semakin mahal.

\section{Landasan Teori \\ 2.1 Investasi}

Menurut Tandelilin (2010:2) Investasi merupakan komitmen atas sejumlah dana atau sumber daya lainnya yang dilakukan pada saat ini, dengan tujuan memperoleh sejumlah keuntungan di masa yang akan datang.. Tujuan Investasi Pada dasarnya, adalah untuk menghasilkan sejumlah uang. Tetapi secara lebih luas tujuan investasi adalah untuk meningkatkan kesejahteraan para investor

Jenis-jenis investasi yang paling gampang dan paling aman adalah sebagai berikut:

a. Tabungan adalah Konsep tabungan tyang sudah mendarah daging dalam kehidupan kita, konsep tersebut mengajak kita untuk menyimpan sisa dana yang ada. dana yang disimpan adalah sisa dana, berarti banyak orang yang mengatakan bahwa tidak memiliki tabungan karena tidak memiliki sisa lagi dari penghasilannya.

b. Deposito Dalam deposito, ada beberapa komponen yang harus diperhitungkan selain bunga, yaitu tenor waktu dan juga penalti. Tenor merupakan jangka waktu dana yang disimpan tidak boleh diambil, misalnya satu bulan, tiga bulan, enam bulan, atau dua belas bulan. Selama jangka waktu tersebut, kita akan mendapatkan bunga sesuai dengan yang dijanjikan. Jika kita terpaksa mencairkan deposito yang kita miliki sebelum jatuh tempo, kita akan dikenai biaya penalti.

c. Investasi properti merupakan pembelian terbesar dalam hidup seseorang Pertumbuhan properti jauh lebih lambat dibandingkan dengan pertumbuhan manusia sehingga tidak mengherankan jika harganya hampir selalu naik dari waktu ke waktu.

d. Emas merupakan logam mulia yang sangat diminati oleh banyak orang. Orang rela mengeluarkan dana yang cukup besar untuk mendapatkan logam mulia yang memiliki beragam bentuk ini. 


\subsection{Saham}

Saham merupakan salah satu jenis investasi yang menjajikan keuntungan bagi para investor. Saham yang diperoleh melalui pembelian atau dengan cara lain, memberikan hak kepada pemegang saham yang lain sesuai dengan investasi yang ada pada perusahaan tersebut. Brigham and Houston (2009) saham adalah surat tanda pernyataan modal pada suatu perseroan terbatas. Seseorang membeli saham berarti orang tersebut ikut memiliki perusahaan yang menerbitkan sahm, sehingga ia mempunyai klaim atas penghasilan dan aktiva perusahaan tersebut.

Keown et al (2011) ada beberapa konsep tentang nilai suatu harga saham yaitu:

a. Nilai Nominal merupakan Nilai yang tertera pada lembaran saham, nilai nominal ini tidak mengukur nilai ril suatu saham tetapi merupakan nilai yang digunakan untuk menentukan besarnya modal disetor yang dilaporkan pada neraca perusahaan.

b. Nilai Buku (Book Value) merupakan Nilai yang menunjukan nilai aktiva bersih perlembar saham yang dimilki oleh pemegang saham.

C. Nilai pasar (Market Value, Market Price) Merupakan Nilai suatu saham yang ditentukan oleh suatu permintaan dan penawaran saham dibursa efek. Nilai pasar inilah yang menentukan besarnya Indek Harga Saham Individual dan Indek Harga Saham Gabungan (IHSG).

d. Nilai Fundamental atau Nilai Intrinsik (Intrinsic Value) merupakan Nilai atau harga yang wajar dari suatu saham yang mencerminkan nilai riilnya (Riil Value). Nilai intrinsic yang digunakan oleh investor untuk melakukan penilaian terhadap sahamnya yaitu dengan cara membandingkan nilai intrinsic dengan nilai pasar dapat diketahui apakah saham telah mengalami Overpriced atau masih Undrpriced.

Jenis-jenis saham berdasarkan hak tagihan Menurut Hermuningsih (2011) saham berdasarkan hak tagihan menjadi 2 yaitu: Saham Biasa (Common Stock) dan Saham Preferen (Preferred Stock).

\subsection{Return Saham}

Return saham merupakan pendapatan per lembar saham yang dimilik oleh para investor. salah satu faktor yang memotivasi investor berinvestasi dan juga merupakan imbalan atas keberanian investor menanggung risiko atas investasi yang dilakukannya. Wahyudi (2003), return saham adalah keuntungan yang dinikmati investor atas investasi yang dilakukannya. Return juga mempunyai dua komponen yaitu current income dan capital gain. Bentuk dari current income merupakan keuntungan yang diperoleh melalui pembayaran yang bersifat periodik, seperti keuntungan berupa dividen yang merupakan bentuk dari hasil kinerja fundamental perusahaan. Sedangkan capital gain berupa keuntungan yang diterima karena selisih antara harga jual dan harga beli suatu instrumen investasi. Besarnya capital gain akan positif bila harga jual saham yang dimiliki lebih tinggi dari harga belinya.

Menurut definisi di atas, maka dapat kesimpulan bahwa return saham adalah tingkat keuntungan atau laba yang diperoleh oleh para investor dari investasi pada sahamnya dan berdasarkan selisih perubahan seharga saham periode sekarang dengan periode sebelumnya.

\subsection{Debt To Equity Ratio (DER)}

Rasio ini menunjukkan perbandingan utang dan modal. Selain itu rasio ini dinilai sangat penting karena memberi pengaruh positif dan negatif terhadap rentabilitas modal sendiri dari perusahaan tersebut. Semakin tinggi rasio ini maka semakin rendah kemampuan modal sendiri dalam menjamin hutang jangka panjangnya, sehingga akan semakin berisiko bagi perusahaan dan begitu pula jika sebaliknya. Perhitungan Debt to Equity Ratio (DER). dirumuskan sebagai berikut:

Debt to Equity ratio $=\frac{\text { Total Hutang }}{\text { Total Modal }}$

\subsection{Rasio Pasar}

Rasio pasar bertujuan untuk menjadi tolak ukur yang dapat menghubungkan harga saham biasa dengan pendapatan perusahaan dari nilai perbuku saham. Dengan kata lain dpat disimpulkan rasiopasar ini mencerminkan performance perusahaan secara keseluruhan yang mengaitkan kondisi internal dengan kondisi pasar (Sugiono, 2009:84). 


\subsection{Price to Book Value (PBV)}

Rasio ini menggambarkan seberapa besar pasar menghargai nilai buku saham suatu perusahaan. Makin tinggi rasio ini, berarti pasar makin percaya akan prospek perusahaan tersebut, begitu pula sebaliknya. Perhitungan Price to Book Value (PBV) dirumuskan sebagai berikut:

$P B V=\frac{\text { Harga saham Persaham }}{\text { Nilai buku Persaham }}$

\subsection{Earning Per Share (EPS)}

Earning Per Share merupakan rasio yang mencerminkan kemampuan tas perusahaan dalam menghasilkan laba untuk setiap lembar saham yang beredar , menurut Darmidji (2012;154). Rasio ini juga menunjukan bagian tiap laba pada setiap saham, EPS menggambarkan profitabilitas perusahaan yang tergambar pada setiap lembar saham. Makin tinggi nilai EPS tentu saya menggembirakan pemegang saham karena makin besar tingkat laba yang disediakan untuk pemegang saham dan kemungkinan peningkatan jumlah deviden yang diterima pemegang saham. Perhitungan Earning Per Share (EPS) dirumuskan sebagai berikut:

$E P S=\frac{\text { Laba Bersih }}{\text { Jumlah Saham Beredar }}$

\subsection{Total Asset Turn Over}

Rasio ini menunjukkan kemampuan perusahaan dalam mengelola seluruh asset atau investasi untuk menghasilkan penjualan. Karena itu Semakin besar nilai rasio ini maka semakin bagus kemampuan perusahaan dalam mengelola asetnya, begitu pula sebaliknya. Perhitungan Total Asset Turn Over (TATO) dirumuskan sebagai berikut:
Total Asset Turn Over $=\frac{\text { Pejualan }}{\text { Total Aktiva }}$

\section{METODE PENELITIAN}

\subsection{Populasi dan Sampel}

Pada penelitian ini menggunakan populasi yaitu prusahaan- perusahaan property yang terdaftar di Indeks saham syariah Indonesia (ISSI) periode 2016-2018 .Populasi perusahaan dalam penelitian ini sebanyak 24 perusahaan. Dan pengambilan sampel dalam penelitian ini adalah perusahaan property yang terdaftar di ISSI (Indeks Saham Syariah Indonesia) yang dipilih menggunakan metode sampling. Alasan menggapa menggunakan metode sampling karena teknik penentuan sampel dalam pertimbangan waktu tertentu. Sampel dalam penelitian ini harus memenuhi kreteria pemilihan sampel berikut ini yaitu Mempublikasikan laporan tahunan dan laporan keuangan dari tahun 2016-2018 dan Perusahaan melaporkan laba yang positif dan mempublikasikan laporan keuangannya dengan menggunakan tahun buku yang dimulai pada 1 januari sampai 31 Desember serta Perusahaan menyajikan laporan keuangan dengan satuan rupiah. Jadi jumlah sampel yang memenuhi kriteria adalah 10 perusahaan.

\subsection{Teknik Pengumpulan Data}

Untuk memperoleh data yang diperlukan dalam penelitian ini, penulis mengumpulkan data dengan metode studi dokumentasi. Metode ini dilakukan dengan cara mengumpulkan laporan keuangan tahunan, dan melakukan penelaahaan data-data dan informasi yanag akan digunakan seperti laporan tahunan yang terdaftar di ISSI (Indeks Saham Syariah Indonesia) pada periode 2016-2018.

\section{Hasil Penelitian}

\subsection{Analisis Deskriptif}

Tabel 1 Deskripstif

\begin{tabular}{|l|r|r|r|r|r|}
\hline \multicolumn{7}{|c|}{ Descriptive Statistics } \\
\hline & $\mathrm{N}$ & Minimum & Maximum & \multicolumn{1}{c|}{ Mean } & Std. Deviation \\
\hline DER & 30 & .11 & 25.60 & 2.1080 & 4.56265 \\
\hline PBV & 30 & -.33 & 3.03 & .8683 & .71642 \\
\hline TATO & 30 & .01 & 5.22 & 1.4970 & 1.44909 \\
\hline RETURN & 30 & .17 & 4.05 & 1.4487 & 1.17927 \\
SAHAM & & & & & \\
\hline Valid N (listwise) & 30 & & & & \\
\hline
\end{tabular}

Data olahan SPSS Versi 25,00 Tahun 2020 
Berdasarkan table 1 dapat dilihat bahwa diperoleh keterangan terlihat DER (Debt to equity ratio ) dengan nilai terendah atau nilai minimum adalah 0.11 sedangkan nilai tertinggi atau maksimum sebesar 25.60 dengan nilai ratarata 2.1080 dan standar deviasi 4.56265. Sedangkan dapat dilihat dari variabel PBV (Price Book Value) dengan nilai terendah atau nilai minimum adalah -0.33 dan nilai tertinggi atau nilai maksimum adalah 3.03 dengan nilai ratarata 0.8683 dan standar deviasi 0.71642 . Kemudian dapat dilihat dari variabel TATO (Total Assets Turn Over) dengan nilai terendah atau nilai minimum adalah 0.01 sedangkan nilai tertinggi atau maksimum adalah 5.22 dengan nilai rata-rata adalah 1.4970 dan standar deviasi adalah 1.44909. Selanjutnya dapat dilihat dari variabel Y yaitu Return Saham menunjukan nilai terendah atau minimum adalah 0.17 dan nilai tertinggi atau maksimum adalah 4.05 dengan nilai rata-rata 1.4487 dan standar deviasi adalah 1.17927.

\subsection{Uji Asumsi Klasik 4.2.1 Uji Normalitas}

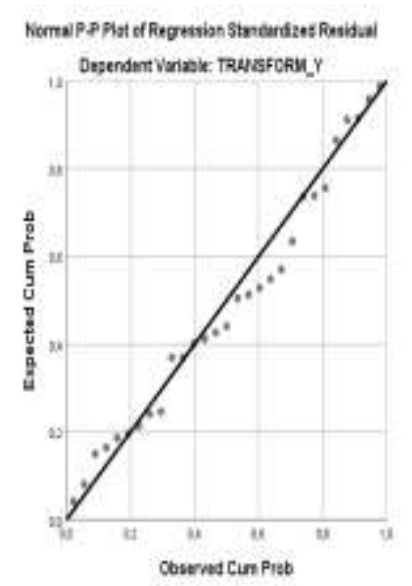

Gambar 1 Grafik Normal Plot

Dapat dilihat bahwa grafik histogram memberikan pola terdistribusi yang tidak melenceng ke kiri dan ke kanan. Dengan demikian dapat disimpulkan bahwa residual terdistribusi secara normal. Sedangkan pada grafik normal P-Plot didapatkan pola distribusi dengan titik-titik menyebar berhimpit di sekitar diagonal dan kedua hal ini menunjukkan bahwa residual terdistribusi secara normal.

\subsubsection{Uji Multikoloinearitas}

Tabel 2 Uji Multikoloniearitas

\begin{tabular}{|c|c|c|c|c|c|c|c|c|}
\hline \multicolumn{9}{|c|}{ Coefficients $^{\mathrm{a}}$} \\
\hline & & \multicolumn{2}{|c|}{$\begin{array}{l}\text { Unstandardized } \\
\text { Coefficients }\end{array}$} & \multirow{2}{*}{$\begin{array}{c}\begin{array}{c}\text { Standardized } \\
\text { Coefficients }\end{array} \\
\text { Beta }\end{array}$} & \multirow[b]{2}{*}{$\mathrm{T}$} & \multirow[b]{2}{*}{ Sig. } & \multicolumn{2}{|c|}{$\begin{array}{c}\text { Collinearity } \\
\text { Statistics }\end{array}$} \\
\hline \multicolumn{2}{|c|}{ Model } & B & Std. Error & & & & Tolerance & VIF \\
\hline \multirow[t]{5}{*}{1} & (Constant) & -.026 & .204 & & -.128 & .899 & & \\
\hline & LN_X1 & -.067 & .166 & -.085 & -.403 & .690 & .867 & 1.153 \\
\hline & LN_X2 & .0 & .171 & .047 & .237 & .815 & .972 & 1.029 \\
\hline & & 40 & & & & & & \\
\hline & LN_X3 & .084 & .140 & .128 & .601 & .553 & .849 & 1.178 \\
\hline
\end{tabular}

Data Olahan SPSS 25,00 Tahun 2020

Pada hasil perhitungan yang ditujukan oleh table multikolinearitas, dimana dapat dilihat bahwa variabel yang digunakan dalam penelitian ini memiliki nilai tolerance yang lebih dari 0,1 dan nilai VIF yang kurang dari 10. Hal ini berarti bahwa tidak ada gejala multikolinnearitas antar seluruh variabel independen dalam penelitian ini, sehingga dapat dikatakan model yang berbentuk adalah model regresi yang baik dan layak digunakan dalam penelitian.

\subsubsection{Uji Autokorelasi}

Runt Test adalah salah satu analisis nonparametik yang digunakan untuk menguji apakah residul terdapat korelasi yang tinggi, Test ini digunakan untuk melihat apakah data residul terjadi secara acak atau tidak. Adapun hasil uji 
autokorelasi penlitian ini, dapat dilihatpada gamabar dibawah ini:

Tabel 3 Uji Run Test

\begin{tabular}{|l|r|}
\hline \multicolumn{2}{|c|}{ Runs Test } \\
\hline & LAG_RES \\
\hline Test Value & .19 \\
\hline Cases $<$ Test Value & 14 \\
\hline Cases $>=$ Test Value & 14 \\
\hline Total Cases & 28 \\
\hline Number of Runs & 10 \\
\hline$Z$ & -1.733 \\
\hline
\end{tabular}

\begin{tabular}{|l|r|}
\hline $\begin{array}{l}\text { Asymp. Sig. (2- } \\
\text { tailed) }\end{array}$ & .083 \\
\hline a. Median \\
\hline Data Olahan SPSS Versi 25,00 Tahun 2020
\end{tabular}

Dari hasil SPSS pada table 5.3 diatas telah diperolejh nilai Asymp. Sig (2-tailed) sebesar 0.083 lebih besar dari 0,005 sehingga dapat disimpilkan nilai residul menyebar secara acak dan tidak terdapat gejala atau terjadi masalah autokorelasi dalam persamaan regresi seghingga analisis regresi linear dapat dilanjutkan.

\subsubsection{Uji Heteroskedasitas}

\begin{tabular}{|c|c|c|c|c|c|c|}
\hline \multicolumn{7}{|c|}{ Tabel 4.Uji Glejser } \\
\hline \multirow{2}{*}{\multicolumn{2}{|c|}{ Model }} & \multicolumn{2}{|c|}{ Unstandardized Coefficients } & \multirow{2}{*}{$\begin{array}{c}\begin{array}{c}\text { Standardized } \\
\text { Coefficients }\end{array} \\
\text { Beta }\end{array}$} & \multirow[b]{2}{*}{$\mathrm{t}$} & \multirow[b]{2}{*}{ Sig. } \\
\hline & & $\mathrm{B}$ & Std. Error & & & \\
\hline \multirow[t]{4}{*}{1} & (Constant) & ,866 &, 075 & & 11,517 &, 000 \\
\hline & LN_X1 &, 024 & ,061 & ,081 & ,396 & ,695 \\
\hline & LN_X2 & ,086 & ,063 & ,264 & 1,360 &, 186 \\
\hline & LN_X3 &,- 015 &, 051 &,- 059 &,- 283 & ,780 \\
\hline
\end{tabular}

Data Olahan SPSS Versi 25,00 Tahun 2020

Hasil uji diatas dapat diketahui bahwa nilai sig dari masing-masing variabel adalah 0,695 untuk $\mathrm{X}_{1}$, dan 0,186 untuk $\mathrm{X}_{2}$ dan 0,780 untuk $\mathrm{X}_{3}$ pada table sig lebih besar dari >0,005, maka dapat disimpulkan bahwa semua variabel $\mathrm{X}$ tidak mengalami Heteroskedastisitas.

\subsection{Uji Hipotesis}

\subsubsection{Analisis Regresi Linear Berganda}

Tabel 5 Uji Regresi Linear Berganda

\begin{tabular}{|c|c|c|c|c|c|c|}
\hline \multicolumn{7}{|c|}{ Coefficients $^{\mathrm{a}}$} \\
\hline \multirow{2}{*}{\multicolumn{2}{|c|}{ Model }} & \multicolumn{2}{|c|}{ Unstandardized Coefficients } & \multirow{2}{*}{$\begin{array}{c}\begin{array}{c}\text { Standardized } \\
\text { Coefficients }\end{array} \\
\text { Beta }\end{array}$} & \multirow[b]{2}{*}{$\mathrm{t}$} & \multirow[b]{2}{*}{ Sig. } \\
\hline & & $\mathrm{B}$ & Std. Error & & & \\
\hline \multirow[t]{4}{*}{1} & (Constant) & -.026 & .204 & & -.128 & .899 \\
\hline & LN_X1 & -.067 & .166 & -.085 & -.403 & .690 \\
\hline & LN_X2 & .040 & .171 & .047 & .237 & .815 \\
\hline & LN_X3 & .084 & .140 & .128 & .601 & .553 \\
\hline
\end{tabular}

a. Dependent Variable: $L N_{-} Y$

Data Olaha SPPS Versi 25,00 Tahun 2020

Hasil pengujian dengan metode regresi linear berganda diatas menguji pengaruh variabelvariabel independent DER (Debt to Equity Ratio), Price Book Value (PBV), TATO (total Assets Turn Over) terhadap Return Saham maka dapat disusun sebuah persamaan berikut: $Y=0,026-0,067 X_{1}+-0,040 X_{2}+0,084 X_{3}+e$
Persamaan regresi diatas mempunyai makna sebagai berikut :

1) Konstanta sebesar 0,026 menyatakan bahwa jika variabel independen dianggap bernilai nol, maka Return Saham bernilai sebesar 0,026 . 
2) Koefisien regresi $X_{1}$ (Debt to Equity Ratio ) dari perhitungan linear berganda dapat dilihat sebesar 0,067 hal ini berarti setiap ada peningkatan biaya operasional sebesar 1 satuan maka Retun Saham akan meningkat 0,067 satuan. Sebaliknya, setiap ada penurunan Debt to Equity Ratio sebesar 1 satuan maka Retun Saham turun sebesar 0,067 satuan.

3) Koefisien regresi $X_{2}$ (Price Book Value) dari perhitungan linear berganda dapat dilihat 0,040 hal ini berarti setiap ada peningkatan
Price Book Value sebesar 1 satuan maka Return Saham akan menurunkan sebesar 0,040 satuan. Sebaliknya setiap ada penurunan Price Book Value sebesar 1 satuan maka Return saham akan meningkat sebesar 0,040 satuan.

4) Koefisien regresi $X_{3}$ (TAT0) dari perhitungan linear berganda dapat dilihat 0,084 hal ini setiap peningkatan TATO sebesar 1 persen diprediksi akan meningkatkan pendapatan Return Saham sebesar 0,084 dengan asumsi Retun Saham tidak berubah.

\subsubsection{Uji T}

Tabel 6. Output Hasil Uji T

\begin{tabular}{|c|c|c|c|c|c|c|}
\hline \multicolumn{7}{|c|}{ Coefficients $^{\mathrm{a}}$} \\
\hline \multirow{2}{*}{\multicolumn{2}{|c|}{ Model }} & \multicolumn{2}{|c|}{ Unstandardized Coefficients } & \multirow{2}{*}{$\begin{array}{c}\begin{array}{c}\text { Standardized } \\
\text { Coefficients }\end{array} \\
\text { Beta }\end{array}$} & \multirow[b]{2}{*}{$\mathrm{t}$} & \multirow[b]{2}{*}{ Sig. } \\
\hline & & $\mathrm{B}$ & Std. Error & & & \\
\hline \multirow[t]{4}{*}{1} & (Constant) & -.026 & .204 & & -.128 & .899 \\
\hline & LN_X1 & -.067 & .166 & -.085 & -.403 & .690 \\
\hline & LN_X2 & .040 & .171 & .047 & .237 & .815 \\
\hline & \begin{tabular}{|l|} 
LN_X3 \\
\end{tabular} & .084 & .140 & .128 & .601 & .553 \\
\hline
\end{tabular}

Data Olahan SPSS Versi 25,00 Tahun 2020

Berdasarkan hasil uji pada tabel diatas maka dapat diambil kesimpulan sebagai berikut ,Debt To Equity Ratio memiliki nilai yang tidak signifikan sebesar 0,690>0,05 maka hipotesis ditolak. Ini berarti variabel tersebut tidak berpengaruh signifikan terhadap Retun Saham. Price Book Value memiliki nilai yang signifikan sebesar $0,815<0,05$ maka hipotesis diterima.

\subsubsection{Uji Koefisien Determin $R^{2}$}

Tabel 7 Uji Hasil Analisis Koefisien Determin

\begin{tabular}{|l|c|r|c|r|}
\hline \multicolumn{5}{|c|}{ Model Summary } \\
\hline Model & $\mathrm{R}$ & R Square & $\begin{array}{c}\text { Adjusted R } \\
\text { Square }\end{array}$ & $\begin{array}{c}\text { Std. Error of } \\
\text { the Estimate }\end{array}$ \\
\hline 1 & $.179^{\mathrm{a}}$ & .032 & -.084 & .96461 \\
\hline \multicolumn{5}{|c|}{ a. Predictors: (Constant), LN_X3, LN_X2, LN_X1 } \\
\hline
\end{tabular}

Tabel memperlihatkan nilai koefisien determinasi (adjust R) yang diperoleh sebesar 0,084 atau sebesar $0,84 \%$. Hal ini menunjukan Variabel Debt to Equity Ratio, Price Book Value dan Total Assets Turn Over berkontribusi sebesar $9,16 \%$ dipengaruhi bvariabel lainnya yg tidak diteliti didalam penelitian ini.
Hal ini berarti variabel tersebut berpengaruh negatif terhadap Return Saham. Total Asset Turn Over memiliki nilai yang tidak signifikan sebesar 0,553> 0,05 maka hipotesis ditolak. Hal ini berarti variabel tersebut tidak berpengaruh terhadap Return Saham.
5 Kesimpulan

Dari hasil uji yang telah dilakukan pada bab sebelumnya dalam penelitian ini, maka dapat disimpulkan :

1. Secara parsial variabel Debt To Equity berpengaruh negatif dan tidak signifikan terhadap Return Saham, yang berarti penurunan Debt to Equity Ratio tidak disertai dengan kenaikan pendapatan Return Saham 
sehingga tidak ada perubahan hasil secara signifikan.

2. Secara Parsial variabel Price Book Value berpengaruh signifikan dan memiliki arah yang negatif terhadap Return Saham.

3. Secara parsial variabel Total Asset Turn Over tidak berpengaruh signifikan terhadap Return Saham, sehingga dapat disimpulkan bahwa semakin tinggi tingkat Total Asset Turn Over maka tidak akan mempengaruhi pendapatan Return Saham pada Perusahaan property. Hal tersebut karena likuiditas berasal dari modal inti, kuasi ekuitas, sehingga semakin tinggi Return Saham maka pendapatan margin juga akan semakin tinggi.

\section{DAFTAR PUSTAKA}

Brigham \& Houston. (2010). "Pengaruh Variabel Keuangan terhadap Penentuan Harga Pasar Saham Perusahaan Sesudah Penawaran Umum Perdana". Dasar-dasar Manajemen Keuangan Buku 1 (edisi:11), Jakarta : Salemba Empat .Manajemend an Akuntansi.

Darmadji, (2012). "Pengaruh ROA, DER, PER dan Earning Ratio Terhadap Harga Saham".

Deviana, N. (2016). "Pengaruh Debt To Equity Ratio, Total Assets Turn Over, Return On Assets Terhadap Return Saham".

Fahmi, Irham. (2012). "Pengaruh Informasi Akuntansi Terhadap Kapitalisasi Pasar di Bursa Efek Jakarta".

Hamidy (2014). "Pengaruh Struktur Modal terhadap Nilai Perusahaan Dengan Propitabilitas Sebagai Interpening". Tesis Universitas Udayana. Denpasar.

Ihsan., Sri Murni., dan Jacky. (2017). "Pengaruh Current Ratio, Debt to Equity Ratio, dan Return On Asset terhadap return saham pada perusahaan auto motif dan komponen periode 2013-2015". Jurnal EMBA. Vol.5, No.2, Juni 2017, Hal. 1793-1803

Jogiyanto, (2003). “Teori Fortofolio dan Analisis Investasi". Cetakan Kedua. Badan Penerbit Fakultas Ekonomi. Yogyakarta.

Jogiyanto, (2008). "Teori Portofolio dan Analisis Investasi”. BPFE, Yogyakarta.”

JumawandanKasran. (2017). "Profitability, Earning Per Share on stock returns and the role of size as a moderating variable in stateowned companies listed in the IDX in the period of 2011-2016".
Kasmir, (2003). "Bank Dan Lembaga Keuangan lainnya". Indeks. Jakarta.

Kuncoro, (2009). "Metode Riset Untuk Bisnis dan Ekonomi". Penerbit Erlangga. Jakarta.

Khairani., Emrinaldi., dan Raja. (2014). "Pengaruh Current Ratio, Debt to Equity Ratio, Return On Equity, Price Earning Ratio, dan Earning Per Share terhadap return saham pada perusahaan properti dan real estate yang terdaftar di BEI tahun 2009-2011". Jom FEKOM Vol.1.

Nathaniel, Nicky. (2008). "Analisa Faktor-Faktor yang Mempengaruhi Return Saham (Studi pada Saham-Saham Real Estate dan Properti di Bursa Efek Indonesia Periode 2004-2006)". Tesis. Program Studi Megeister Manajemen, Program Pasca Sarjana. Universitas Diponogoro. Semarang.

Pinradee dan Suppanunta. 2014. "Technology Industry on Financial Ratios and Stock Return”. Journal of Business and Economics, Vol.5 No.5 Hal.739- 746. Prasetyo, Bambang dan Lina Miftahul Jannah. (2006). 'Metode Penelitian Kuantitatif: Teori dan Aplikasi”. Jakarta: PT Raja Grafindo Persada. 105

Esti. (2005.) "Pengaruh Earning Per Share, Price Earning Ratio, dan Debt to Equity Ratio Terhadap Return SahamPada Perusahaan Properti Yang Terdaftar di Bursa Efek Jakarta”. Skripsi. Program Studi Ilmu Sosial. Universitas Negeri Semarang.

Sarjono, Haryadi. (2010). "AplikasiRisetOperasi”. Jakarta: SalembaEmpat.

Sawir, Agnes. (2009). “Analisa Kinerja Keuangan dan Perencanaan Keuangan Perusahaan". Jakarta: PT. Gramedia Pustaka Utama.

Sekaran, (2011). "Resrarch Methods For Business". Jakarta: Salemba empat.

Sugiyono. (2009). "Metode Penelitian Kuantitatif, Kuantitatif dan R\&D”.

Tandelilin, Aduardus. (2010). "Fortofolio dan Investasi : Teori dan Aplikasi”. Edisi. Petama. Yogyakarta : Kanisius.

Wahyudi, Sugeng. (2003). "Pengukuran Return Saham”. Jurnal Ekonomi. Suara Merdeka. www.bi.go.id.

www.idx.co.id.

http://www.indonesia-investments.com. 